The Yearbook of the Universities of the Commonwealth, 1953

(Thirtieth Issue.) (Published for the Association of Universities of the British Commonwealth.) Pp. liv + 1805. (London: G. Bell and Sons, Ltd., 1953.) 63s. net. THE Commonwealth Universities' "Yearbook" 1 has become firmly established as a "hardy annual' and one the blooms of which grow bigger with each successive year. The edition for 1953 (the thirtieth) is larger than ever because the staffs and activities of the individual universities are increasing and because new institutions are continually being established. Thus the present edition contains new entries for three Indian universities (Baroda, Bihar and Visva-Bharati) and for one in Pakistan (Karachi); in Canada the Nova Scotia Technical College now has a full entry on becoming a member of the National Conference of Canadian Universities, and in the United Kingdom the entry for Southampton has been moved from the college to the university section.

In Appendix 1 of the "Yearbook" the usual account of the qualifications required for admission to a firstdegree course in United Kingdom universities has been augmented with similar material for Canada, Australia and South Africa. The eight other appendixes have all been revised and in some cases increased, especially Nos. 2 and 3, dealing with United Kingdom postgraduate awards tenable at home and overseas, respectively. The introductory surveys that are to be found at the beginning of each national section have also been considerably revised and, in particular, those for Canada, India and Pakistan completely rewritten. The name index now runs to 151 pages, with a grand total of thirty thousand names.

The seventh quinquennial congress of the universities of the Commonwealth will be held in Cambridge later this year, and this volume should prove of inestimable value to the delegates as a reference work; but its usefulness will not be confined to the congress, for experience shows that this volume is a reference book which quickly shows honourable marks of constant use.

\section{Introduction to Metamathematics}

By Prof. Stephen Cole Kleene. (Bibliotheca Mathematica, Vol. 1.) Pp. $x+550$. (Amsterdam : NorthHolland Publishing Co.; Groningen: P. Noordhoff N.V., 1952.) $32.50 \mathrm{fl}$.

THERE will be a warm welcome for a book of this nature by one who is a distinguished member of the American mathematical fraternity. Outside the Journal of Symbolic Logic, which cannot be expected to be suitable for teaching purposes, it is hard to find an English text wholly fitted for university work in meta-mathematics. The advantage of the present volume is that it contains practically everything necessary (somewhat massive as it is) between the same two covers.

There are four main sections, namely, the problem of foundations, mathematical logic, recursive functions, and some additional topics in mathematical logic. Actually, the last is almost a supplement dealing with the predicate calculus and consistency proofs. It may not always be wholly advisable to follow the author's preference for starred and unstarred paragraphs : the same applies in general to an encounter with Gödel's two famous theorems before tackling the lemma establishing the primitive recursive character of certain predicates. But these are details. The main strength of the development followed by Prof. Kleene stands out at the end of Part 1, where he collates the essential ingredients of the 'full picture'. These are $(a)$ the informal theory, (b) the object theory, and (c) the meta-theory, in which $(b)$ is examined.

An adequate bibliography, a list of symbols and notations, and an index bring a most valuable compilation to a close. F. I. G. RawLINS

\section{Chemistry in Action}

By Prof. George M. Rawlins and Alden H. Struble. Second edition. Pp. viii +575 . (Boston, Mass. : D. C. Heath and Co.; London: George G. Harrap and Co., Ltd., 1952.) $21 s$.

1 HIS book describes a one-year course in chemistry for American high-schools. The author's plan seems to be to make chemistry attractive by stressing fascinating applications of it to everyday affairs. The scope covers approximately the requirements of the British matriculation syllabus, with the addition of more than a hundred pages on hydrocarbon chemistry; this permits alluring diseussions on such topics as textiles, food, penicillin, stain-removal and insecticides. The whole is built on a rather slight framework of theory. The book is replete with illustrations ; most of the half-tone plates illustrate not fundamental principles but interesting and occasionally sensational applications of the science. Much information is given in the form of tables, and some by picture and caption only. There are many sets of questions and numerous reading references.

The worth of the book is its content of interesting up-to-date factual matter. Pleasing to look at and read, it would serve to acquaint a non-scientist with the role of chemistry in everyday life. There is too little of the grammar of science for the book to be used in Britain as an examination text, but, as a supplementary reader or as an aid to a teacher to brighten his lessons, it is worth consideration.

$$
\text { G. F. }
$$

\section{General Genetics}

By Adrian M. Srb and Ray D. Owen. (A Series of Biology Texts.) Pp. $x+561$. (San Francisco: W. H. Freeman and Co.; London: Bailey Bros. and Swinfen, Ltd., 1952.) 5.50 dollars ; $47 s$.

A $\mathrm{S}$ a text-book for courses in elementary general A genetics, this book constitutes a welcome addition. There are features which make it valuable, though unfortunately the price is not one of these. First, there is novelty and variety in the choice of examples; second, the illustrations are particularly effective; third, the developments of the past ten years are amply dealt with; and fourth, there is a very salutary discussion of the principles involved at every step in the logical sequence of the chapters. This last quality ensures that the student will be well aware of the fields in which genetical theory is most promising and of those in which it is weaker. Among the criticisms which might be made, one is shared with all other previous text-books, namely, the inconsistent use of the words "gene", "allele" and "locus", though, of course, a good deal of the inconsistency is in the nature itself of the concepts. Another criticism is that the chapters on quantitative inheritance and on population genetics are rather slight. On the whole, this text-book is likely to be useful to those who-have the task of teaching elementary genetics to students who have a varied background and not much of it at that.

G. Pontecorvo 